\title{
Novice Teachers' Perspectives on the Use of Languages in French as a Second Language Classes That Include English Language Learners
}

Callie Mady

Nipissing University

Katy Arnett

St. Mary's College of Maryland

\begin{abstract}
In the Canadian context, although most considerations for home-target language use are centred on the presence of English in French Second Language (FSL) programs, the increasing number of immigrants to Canada in general and to southern Ontario in particular has provided an impetus to extend the discussion to include the use of languages beyond Canada's official languages. Through the use of questionnaires with novice teachers pre-and post-Bachelor of Education programs and interviews for 3 years following graduation, this study sought to explore novice teachers' perspectives on the use of languages in FSL classes that include English language learners (ELLs). Novice teachers consistently identified the need to maximize French use, minimize English use, and include languages from students' language repertoires as useful means to support the FSL acquisition by ELLs. In addition, the novice teacher participants revealed a preference for ELLs to be included in core French as opposed to immersion programming. Participants' consideration of English and languages other than French were limited to teacher use. Additional teacher reflection on if and when to provide space for students to use all their language knowledge may prove advantageous to supporting plurilingual development.
\end{abstract}

Keywords: target language use; multilingual language acquisition; second language education; French as a second language, teacher beliefs

Callie Mady is the Associate Dean of the Schulich School of Education, Nipissing University, North Bay, ON, Canada. She holds a PhD from OISE of the University of Toronto with a focus on second language education. Her research interests include French as a second language education and multilingual language acquisition. In particular, her research focuses on minority populations in those areas — immigrants and students with learning difficulties. calliem@nipissingu.ca

Katy Arnett, Ph.D., is a Professor of Educational Studies at St. Mary's College of Maryland, where she teaches undergraduate and graduate courses focused on English learners and technology in the classroom. A former Fulbright Scholar, her scholarly work focuses on different dimensions of inclusion within second language contexts. kearnett@ smcm.edu 
Second language teachers continue to be regularly challenged to consider the role and space afforded to their students' home languages within the learning environment and often assume that the home language(s) and the school language (i.e., English within this study's context) are the same. As is the case with most controversies within education, there is a continuum of views, ranging from perspectives that advocate for exclusive target language use (e.g., Atkinson, 1993) to those that see a place for the students' home language(s) as a way to navigate confusion and honour the reality that the students are bi/multilingual individuals who are naturally working to find connections between the target language and their home language(s) (American Council on the Teaching of Foreign Languages, 2010; Cook, 2001; Turnbull, 2001). Where one's practice is individually situated on the continuum reflects personal belief systems (e.g., Arnett \& Turnbull, 2007; Turnbull \& Arnett, 2002), the context in which the language program is situated (Mady \& Arnett, 2017), the type of language program (e.g., bilingual; dual immersion; foreign language) (e.g., Palmer, Mateus, Martínez, \& Henderson, 2014), the teacher's proficiency with the target language (e.g., Chambless, 2012), teachers' perceptions of the students' skills with the target and home languages (e.g., Lo, 2015), the content of the lesson (e.g., Levine, 2014), and perhaps additional factors, or any combination thereof.

In the Canadian context, although most considerations of the home-target language use are centred on the presence of English in French Second Language (FSL) programs, whether they be French immersion (e.g., Culligan, 2015), intensive French (e.g., Netten \& Germain, 2005, 2009), or core French ${ }^{\text {i }}$ (e.g., Calman \& Daniel, 1998; Howard, 2006; Salvatori, 2007), the increasing number of immigrants to Canada has provided an impetus to extend the discussion to include the use of languages beyond Canada's official languages. The factors mentioned in the previous paragraph have been evidenced in these research studies, but research (e.g., Mady, 2013) focused on the educational experience of a particular learner population-English language learners (ELLs) - has also revealed FSL teachers' perspectives linked to the role of English and home languages in FSL classrooms as means to support the minority group's FSL acquisition. Though teachers' language use patterns were not initial considerations of the research projects, the results from these studies added insight into the use of English in the French classroom. It should be noted that these studies occurred in classrooms from Grade 6 and above where the overall student population is generally presumed to have a solid command of English; we do not, however, explore students' English skills as a part of this review.

In her observations of two Grade 6 core French teachers instructing eight FSL classes, in a context where ELLs formed approximately $50 \%$ of the classroom population, Mady (2013) also discovered a variety of practices pertaining to teacher language use. Teacher A used a mixture of French and English whereas Teacher B taught almost exclusively in French. Although Teacher B shared a home language (i.e., Punjabi) with the majority of her students, she did not make reference to it during the observations that covered five classes. It is noteworthy that the students in the classes followed the teachers' example of language use. In other words, the students in Teacher A's classes used English frequently while students in Teacher B's class rarely used English. Neither group used a language other than French or English. Mady also conducted semistructured interviews with the teachers. It is worth highlighting that Teacher A, who frequently used English in class, acknowledged the language use debate stating her judgment that such translation should be avoided. This declaration underscores the potential for teachers' practice to be contrary to their beliefs when considering English language use. Such a discrepancy may be influenced by the curriculum's statement that French is the language of FSL classes (Ontario Ministry of Education, 1998, p. 4) without acknowledgement of other language use. Although 
not observed, both teachers in the study recognized that use of ELLs' prior knowledge includes use of their home languages by the teacher highlighting commonalities among languages. While research (e.g., Jessner, 2008; Kemp, 2007) in additional language learning contexts supports the use of students' languages in order to increase students' metalinguistic awareness and strategy use as means to improve language acquisition, other research highlights the necessity of the teacher to make explicit reference to students' language knowledge in order for students to access such resources (e.g., Castelotti \& Moore, 2005; Moore, 2006).

This research thus shows a tendency to use English as an adaptation to instruction in order to support students' French acquisition. Although the Canadian student population has changed to include students from a wide range of language backgrounds and competencies, the limited available research shows a continued use of English without teacher attention being brought to the other languages represented in the classroom, as well as an apparent assumption that English is of equal benefit to all students in the classroom. Given research that underscores the importance of the teacher to make explicit reference to connections between languages in order for multilinguals to access bilingual advantages associated with language learning (e.g., Grosjean, 2008; Herdina \& Jessner, 2002), this study sought to examine novice teachers' perspectives of language use in their FSL classrooms.

\section{Conceptual Framework}

For FSL teachers to consider the intentional use of languages other than French in the FSL classroom, a shift from the former curriculum's recommendation of sole use of French to one where students' FSL acquisition could benefit from using all of students' linguistic resources may prove to be beneficial. Whether the new curriculum (Ontario Ministry of Education, 2013), introduced post- data collection, that recognizes students' languages as resources will expedite such a shift remains unexplored. In addition to studies that examine the benefits of using one language to inform the acquisition of another (Cummins, 2001; Grosjean, 2008; Herdina \& Jessner, 2002), the diverse array of students' languages in a southern Ontario context necessitates an examination of a plurilingual framework and accompanying research. In the context of this present study, plurilingual refers to ELLs, that is to say learners who can use more than two languages to communicate. A plurilingual framework recognizes that while students' language competencies vary, the combined accumulation of such competencies serves as a resource that can enhance additional language learning (Cummins, 2008). Practical implementation of such a framework includes the use of multiple languages in a learning context in order to reveal linkages (Coste, Moore, \& Zarate, 2009) that may lead to enhanced metacognition and strategy use potentially resulting in improved language acquisition. In her research with Chinese immigrant children in French immersion, Moore (2010) revealed, through image-based research, that young children (i.e., 6 and 7 years old) draw upon and benefited from their multiple competencies to complete a task provided in the classroom language (i.e., French), thereby demonstrating how a plurilingual framework positions languages as iterative, dynamic resource bases from which the students can draw (Council of Europe, 2001). Also in a multilingual FSL context in Canada, Moore and Sabatier (2014) worked with teachers to use resources in a variety of languages and observed their implementation. The researchers found that such use supported students' literacy development. Moore and Sabatier, however, qualified that teachers are not yet equipped to undertake plurilingual practices in the FSL class, and while it was not explicitly mentioned in their conclusion, it could be a result of the fact that such a shift requires a shift in viewing other languages as a resource, not only as a benefit to the development of the students. 


\section{Research Questions}

Although English and other languages offer potential resources to support students' FSL acquisition, it is evident from the variety of teacher practices that there is not a common understanding about how to best use said resource. This study aims to respond to the following research questions.

1. How do novice teachers conceptualize language use in FSL classrooms with ELLs?

2. Within novice teachers' thinking about how to support language learners, to what extent is another language a consideration?

3. How do novice teachers consider the ELLs' home language as an influence on their experience with FSL?

In general, we sought the perspectives of novice teachers in recognition of their struggle to apply scientific knowledge related to inclusion learned in the Bachelor of Education (BEd) program to FSL classrooms (Arnett \& Mady, 2018). In particular, research with novice FSL teachers has shown them to struggle with the inclusion of ELLs in FSL classes (Dunn, 2011).

\section{Methodology}

This study sought to examine novice teachers' perspectives on inclusion of ELLs in FSL classes pre- and post-BEd programming. In particular, we explored the teachers' views on the inclusion of ELLs during their BEd year and continued to gather interview data 3 years following graduation. To do so, the study used a mixed-methods approach with a pre- and postBEd questionnaire for both qualitative and quantitative data collection and an interview protocol for more in-depth probing. In the first year of this study, we used the questionnaire and interviews to gather data from novice teachers whereas for the remaining 3 years we gathered data using interviews.

\section{Questionnaire}

The pre-questionnaire was divided into two sections. The first section pertained to the participants' demographic information. The second section included questions regarding the participants' perceptions on inclusion of ELLs in FSL that also served as the post-BEd questionnaire (see Mady \& Arnett, 2017 for full questionnaire). In addition to the quantitative data collected (Arnett, Mady, \& Muilenburg, 2014), the questionnaires gave respondents the opportunity to answer an open-ended question pertaining to strategies used with ELLs. Although no item on the questionnaire addressed the use or importance of languages, the significance of this issue became apparent as the respondents revealed this theme in their responses to the openended question.

\section{Interview Protocol}

A subset of novice teachers were interviewed for this study at the end of their BEd program and once a year for the following 3 years. The participants were asked a series of 14 questions pertaining to their perceptions and experiences with ELLs in FSL. The interviews were audio recorded and then transcribed. Subsequently, a content analysis was conducted to identify themes. Although no question addressed the use of language(s) precisely, use of language and judgment thereof was a consistent theme revealed by the participants over the years. 


\section{Participants}

Questionnaire participants. An invitation to participate in this study was sent to $28 \mathrm{FSL}$ teacher educators in Canada with the request that they share the electronic link to the prequestionnaire with their FSL teacher candidates in the fall of their BEd year. As shown in Table 1, the majority of pre-questionnaire participants were female. Although five regions in Canada were represented, the majority of respondents came from British Columbia.

Table 1

Basic Description of Pre-Questionnaire Participants

\begin{tabular}{ll}
\hline & Pre-questionnaire participants \\
\hline Number of participants: & 78 \\
Gender: & Female $(n=67)$ \\
& Male $(n=10)$ \\
Province of Teacher Education program: & Alberta $(n=2)$ \\
& Atlantic Canada $(n=12)$ \\
& British Columbia $(n=41)$ \\
& Manitoba $(n=14)$ \\
& Ontario $(n=9)$ \\
\hline
\end{tabular}

The participants from the pre-questionnaire who chose to share their email information were subsequently contacted the following April, nearing the end of their program, to complete the post-questionnaire. Whereas 78 participants completed the pre-questionnaire, 48 of the 78 also completed the post-questionnaire. Similar to the pre-questionnaire, the majority of respondents to the post-questionnaire were female and from the province of British Columbia (see Table 2).

Table 2

Basic Description of Post-Questionnaire Participants

\begin{tabular}{ll}
\hline & Post-questionnaire participants \\
\hline Number of participants: & 48 \\
Gender: & Female $(n=41)$ \\
& Male $(n=5)$ \\
& Missing $(n=2)$ \\
Province of Teacher Education program: & Alberta $(n=2)$ \\
& Atlantic Canada $(n=7)$ \\
& British Columbia $(n=23)$ \\
& Manitoba $(n=7)$ \\
& Ontario $(n=9)$ \\
\hline
\end{tabular}

Interview participants. The 48 post-questionnaire respondents were invited to participate in an interview. The first year, a research assistant conducted 15 interviews to target participants' perceptions relating to inclusion of ELLs. The interview data presented in this paper is limited to the 10 participants who completed interviews at the completion of their BEd year and in the years to follow. As with the questionnaire respondents, the majority of interview participants were female (see Table 3 ). Forty percent $(n=4)$ of the interview participants were from Ontario, 
$30 \%(n=3)$ from British Columbia, 20\% from Atlantic Canada $(n=2)$, and 10\% from Manitoba $(n=1)$.

Table 3

Basic Description of Interview Participants

\begin{tabular}{ll}
\hline & Interview participants \\
\hline Number of participants: & 10 \\
Gender: & Female $(n=8)$ \\
& Male $(n=2)$ \\
Province of Teacher Education program: & Atlantic Canada $(n=2)$ \\
& British Columbia $(n=3)$ \\
& Manitoba $(n=1)$ Ontario $(\mathrm{N}=4)$ \\
\hline
\end{tabular}

\section{Findings}

\section{Questionnaire Findings}

The focus of this paper is on FSL teachers' perceptions on the use of languages as considerations in meeting ELLs' needs in an inclusive classroom, as identified by the questionnaire and interview respondents. Given that there was not a direct question pertaining to languages on the questionnaire, the findings presented here are limited to the one open-ended question on the questionnaire: "What strategies would you use to meet the ELLs' needs?" This item provides the most data in response to the second research question of this paper, which considers how teachers conceptualize support of students and if another language is viewed as a support. The pre-questionnaire respondents $(n=78)$ offered 29 different responses. The most frequently given suggestion was to use visuals. The second most common response was to use French as the language of instruction, which is where we first see attention to language as a support in and of itself:

I think if a teacher teaches FSL by speaking exclusively in French and using gestures, etc. to get his/her points across (as opposed to speaking in English or referring to English when something isn't understood), then the students of the class will be on a level playing field irregardless [sic] of whether they are an "English language learner" or not. (Destiny)

To include English learners, I would try and speak only in French as much as possible. (Sean)

For the next two most common types of suggestions, the results revealed specific attention to other languages - first, English, and then the home language of the students. Two representative quotes are provided:

Since I will minimize the use of English in my classroom, the strategies that I use to teach native English-speakers will be the same as I use for English learners. It might even help me to speak English less. (Bethany)

Look for opportunities to include the ELL's first language in class. (Meredith)

As with the pre-questionnaire, the post-questionnaire provided an open-ended question asking the respondents to list the strategies they would use to meet ELLs' needs in the FSL class. In the 
pre-questionnaire, the respondents offered 29 suggestions, while in the post-questionnaire they $(n=48)$ offered 44 different strategies. The two most frequent suggestions remained the same preand post-questionnaires: use of visuals (e.g., images, gestures) and use of French as the language of instruction. In the post-questionnaire, using the students' first languages was mentioned as the third most frequent response. Stacey provides a representative comment: "Using their first language to help them relate to both French and English."

\section{Interview Findings}

Although there was no direct interview question pertaining to languages as a consideration when preparing to include ELLs in FSL, as was the case with the questionnaires, the interviews provided data pertaining to using French as the language of instruction, reducing the amount of English, and using the students' first languages. These data were used mostly to respond to the first and third research questions, respectively, with some additional insight for research question 2. To give additional context to the responses to the interview questions, it is worth noting that in interviews, novice teachers revealed a preference for ELLs to be part of the core French program, rather than immersion, as they judged the core French program to allow them to focus on their English development.

\section{Conceptualizing Language Use in the Classroom}

First and foremost, the novice teachers focused their conceptions of language use on the target language of the classroom: French. Within those data, their use of French were further conceptualized three ways: as a model for students of what they should produce in the classroom, as a tool for equitable access to learning for English learners in the classrooms, and as a support in and of itself for the learning environment. Representative quotes are provided in the order of the themes:

You know, speaking in French as often as we can I think will help because if we are modelling our language, then they will hear what they need to be using especially if they're new to the program and haven't ever had a French class, then they really need to hear how the sentences are structured, and how the sounds go together and things like that. So, I think just using the language and modeling that would be really beneficial to ELL students. (Colleen)

When I teach French I'm just speaking French. ... You just need to experiment a lot of French around him [ELL in class]. So, everything I can in French, I'll do it, and even outside the classroom. (Annalise)

Well, I think the main thing is that you have to be conscious of using French more and not falling back on English you know, because then they're all in the same boat if you're using French all the time. Everyone in the classroom will be in the same, have the same comprehension I guess you'd say, and it would make them all equal, if you rely on English too much at that point then you're probably excluding that one ELL learner because they won't follow the English either. (Sean)

It is worth noting that this last quote from Sean echoes a theme within the open-ended questionnaire data, as evidenced by the included quote from Destiny. 
Part and parcel with many of the responses about the need to maximize the use of French for English learners were clarifications about the role of English in the classroom. Many respondents specifically outlined how English was not used in the classroom and the ways in which they would try to avoid its use. Thus, in relation to research question 2 , we also see many teachers who are not viewing English as a support of student learning in this context. In fact, many of the participants positioned English as part of a wider cultural toolkit that students may not be able to fully use to support their learning:

I use a lot of chiming and visuals and that sort of thing ... and I don't speak English to them either. I tried to incorporate their home culture into my activities. (Roger)

Just trying to use a lot more gestures and pictures, things that are more universal and not specific to the English language. (Terry)

I guess using more visuals instead of relying on English to translate into French. (Whitney)

In addition to Sean's earlier comment, two other interviewees also elaborated that they chose not to use English as it was not helpful for ELLs:

I think the first thing is just constant awareness that the English Language Learner doesn't, for example if you explain things in English that might not help. And that they don't have the same cultural cues necessarily that someone born in Canada might. (Meredith)

You could tell that there were some challenges when I would use some English to try and explain things when they just weren't understanding the French and my gestures, and them just not being able to pick it up and then trying to throw in the English just wasn't very helpful. (Terry)

Although the majority of interviewees agreed that reducing the amount of English in class would be beneficial to ELLs, one interviewee identified the use of English as a strategy to encourage transfer:

Cause really with French there are so many words that are, you know, there are over 80,000 that are the same in French as they are in English, they're just pronounced a little differently, and they mean the same, so there can be so much transfer. (Jenny)

\section{Consideration of Students' First Languages}

Research question 3 was interested in how the novice teachers' viewed and possibly used the students' home language to support their study of French. Without being prompted through a question stem, all of the interviewees recognized that use of ELLs' first languages should also be a strategy to meet ELLs' needs:

It would be easy to apply their native language to learning English and learning French at the same time. (Stacey)

If I know examples from the language that they speak in their home then I will try and use that as well. (Colleen)

One interviewee expanded this further, stating that it would be beneficial to use ELLs' languages in order to provide comparisons to French and thus introducing some thinking about plurilingualism: 
I would try to compare to their native language, and see the best comparisons I could make there, at least to make them feel more comfortable. ... Well depending on what their first language was, like if it was another Latin-based language then I think, for example, a lot of the vocabulary stuff, you can point out the similarities, there might be similarities. (Colleen)

In addition to making comparisons with the ELLs' first languages, teachers linked such comparisons to strategy use:

Like I said, finding more about their native language and how you can compare it to that, and help them learn that way and using the strategies from them learning English. (Colleen)

I think you need to be aware that, yeah I think just being aware of the language of what they speak at home so maybe you could tie some of the similarities in too like those kind of metacognitive skills of like oh, what word does this one look like in your language. Or if there's any similarities at all, so still teaching those strategies, I guess. (Tabitha)

One interviewee recommended using the ELLs' first languages to offer translation:

You are going not from an English to French translation but you are learning that vocabulary from their mother tongue and you will say oh well mi madre [my mother in Spanish] is ma mère [my mother in French] instead of going my mother, ma mère, and just be able to give some of their original language to them. (Jenny)

Although the vast majority of the comments on language use in the FSL class pertained to the teacher's use of language, one interviewee indicated that students would use the ELLs' first language to aid comprehension:

I find sometimes the other kids will transfer into their maternal language to talk, especially the entry level ELL learners, to explain things to them. (Tabitha)

\section{Expectations About English Learning}

Though this was not an initial focus area for this paper, a fourth theme emerged strongly in the data: the extent to which participants were concerned with the English learners' progress in English. This was evidenced through various comments related to their perceptions of the best/worst programming options for English learners.

In addition to considering language use in class, the interview participants revealed that their program recommendations for ELLs are also language dependent. In response to the question of which FSL program would be best/worst for ELLs, the majority of interview participants preferred core French for ELLs so as to allow them more time in English:

The worst, would be I guess immersion in that sense just because if they're, if they're communicating in French all day ideally, it would hinder their practice of English. So they would not be communicating in English as much during the day and they would not be able to develop their skills. (Maria)

I think immersion would be more difficult since their primary language that they would need to be speaking and working on would be English so I would recommend, if I was allowed to give a recommendation, that they would stay in an English program with core French. (Colleen) 
This theme is worth noting because of how some of the participants created a language hierarchy for the English learners. While there was general agreement in the value of FSL study for these learners, there was also an interest in ensuring that progress in English was not slowed due to the program choice for French. English, ultimately, was the language the teachers were most concerned about for their students in the long term. Because this was not a direct question in the research and again, recognizing that these data were collected before the promotion of the plurilingual framework, any further analysis would not be helpful.

\section{Discussion and Conclusion}

In their interviews with the researchers and in their responses to the open-ended question in the pre-and post-BEd questionnaires, the novice FSL teachers in this study considered their use of languages in the classroom in several different ways. First, French was positioned as the "target" to model for students, as a tool of equity for reducing gaps between English learners and their English-speaking peers, and as a support, in general, for helping them advance in the French language. As it pertains to the language use debate in the context of ELLs learning FSL, FSL teachers in this study worked to maximize their French use, minimize the use of the majority language (English), and be open to use of students' home languages. Given that the data stemmed from indirect questions on support of ELLs, their reasons for such choices are means for conjecture. On one hand, given that the majority of FSL teachers in this study reduced their use of English with ELLs in particular supports the potential perspective that ELLs are English deficient and therefore unable to use their English language knowledge as support. Such a perspective is more indicative of a view of language knowledge as segmented rather than that of a plurilingual approach where the underlying competencies are viewed holistically as a resource. Similarly, this choice may also be indicative of teachers' judgment that French cannot be of support for ELLs' English development or perhaps their view that their role is exclusive to FSL development or for fear that English may become more dominant in the classroom. In fact, the presence of ELLs may encourage teachers to maximize the use of French in FSL classes. Macaro (1997) noted that almost exclusive use of the target language was more often found in classes where there were a variety of home languages represented.

However, beyond the English/French language use continuum, FSL teachers in this present study sought to use their knowledge of other languages to support ELLs' FSL development. Teachers suggested using students' languages to provide links to French and draw comparisons as supported benefits of using a plurilingual approach. Although teachers were open to using students' home languages, for the most part such use was limited to teacher rather than student language use thereby limiting language use, for the most part, to the teachers' language repertoires rather than providing space for students to share and use their language repertoires beyond that of the teacher. This is a limitation of this study's focus on teacher language use; it would be beneficial for future research to examine teachers' perspectives on student use of multiple languages in the FSL classroom. Provision of a multilingual space could encourage students to not only use the languages for structural comparisons but also for strategies on how to learn a language (Harris \& Grenfell, 2004).

In addition to choosing when and if to use languages other than French in the FSL classroom, the participants showed a preference for core French to French immersion for ELLs for reasons of increasing their English language development. Such a perspective is congruent with other research. Mady (2011) also found that FSL teachers preferred the core French program option for ELLs due to the perceived higher demands of the French immersion program. It is important 
to note that although this study's participants' perspectives reflect those of other studies, they are contrary to research that shows ELLs' potential to learn English and French in the French immersion program (e.g., Mady, 2013). Whereas the FSL teachers chose when and if to use English to support ELLs' FSL acquisition, they are seemingly unaware of the potential for French to support their English skills. Such a prioritization of English denies research that shows ELLs to be able to add both English and French to their language repertoire to the same level of the Canadian-born peers within the French immersion program (Mady, 2017). Teachers' preference for the core French program may also be associated with the exclusive use of French associated with the direct method often used in French immersion programming.

The above findings highlight the need for BEd teacher educators to not only highlight the potential advantages of a plurilingual approach but also means by which to put it into practice. For example, the FSL teachers in this study may have benefitted from practical examples of ways to create space for students to use languages other than French while still maintaining French as the language of the classroom. In addition, given that the past FSL curriculum document (Ontario Ministry of Education, 1998) underscores the need to have French as the sole language of the classroom and the present document (Ontario Ministry of Education, 2013) lacks direction as to if and how to use other languages to support FSL acquisition, it would be beneficial to have Ministry personnel open the discussion as to if and when the use of other languages is appropriate in an Ontario FSL context. Further to these more practical suggestions, future research may provide support to inform language-choice decisions. Research that informs teachers of a plurilingual approach and follows its practical implementation in core French and French immersion contexts in addition to explicitly exploring teachers' views over time could provide the additional evidence required to better support their students' FSL acquisition. 


\section{References}

American Council on the Teaching of Foreign Languages. (2010). Use of the target language in the classroom. Retrieved from https://www.actfl.org/news/position-statements/use-thetarget-language-the-classroom

Arnett, K., \& Mady, C. (2108). Exemption and exclusion from French Second Language programs in Canada: Consideration of novice teachers' rationales. Exceptionality

Education International, 28, 86-99. Retrieved from https://ir.lib.uwo.ca/eei/vol28/iss1/5

Arnett, K., Mady, C., \& Muilenburg, L. (2014). Canadian FSL teacher candidate beliefs about students with learning difficulties. Theory and Practice in Language Studies, 4(3), 447-457. doi:10.4304/tpls.4.3.447-457

Arnett, K., \& Turnbull, M. (2007). Teacher beliefs in second and foreign language teaching: A state of the art review. In H. J. Siskin (Ed.), AAUSC 2007: From thought to action:

Exploring beliefs and outcomes in the foreign language program (pp. 9-28). Boston, MA: Heinle \& Heinle.

Atkinson, D. (1993). Teaching monolingual classes. London, UK: Longman.

Calman, R., \& Daniel, I. (1998). A board's eye view of core French: The North York Board of Education. In S. Lapkin (Ed.), French second language education in Canada: Empirical studies (pp. 281-323). Toronto, ON: University of Toronto Press.

Castellotti, V., \& Moore, D. (2005). Des politiques linguistiques aux classes de langue : représentations et pratiques du plurilinguisme. In M-A. Mochet, M-J. Barbot, V.

Castellotti, J-L. Chiss, C. Develotte, \& D. Moore (Eds.), Plurilinguisme et apprentissages. Mélanges Daniel Coste (pp. 103-107). Lyon, France: ENS-Éditions.

Chambless, K. S. (2012). Teachers' oral proficiency in the target language: Research on its role in language teaching and learning. Foreign Language Annals, 45(S1), 141-162. doi:10.1111/j.1944-9720.2012.01183.x

Cook, V. (2001). Using the first language in the classroom. The Canadian Modern Language Review, 57, 402-423. doi:10.3138/cmlr.57.3.402

Coste, D., Moore, D., \& Zarate, G. (2009). Plurilingual and pluricultural competence. Strasbourg, France: Council of Europe. Retrieved from https://rm.coe.int/168069d29b

Council of Europe. (2001). Common European framework of reference for languages: Learning, teaching, assessment. Cambridge, UK: Author/Cambridge University Press.

Culligan, K. (2015). Student and teacher perceptions of first language use in secondary French immersion mathematics classrooms. Alberta Journal of Educational Research, 61(1), 1-19.

Cummins, J. (2001). Negotiating identities: Education for empowerment in a diverse society. 2nd ed. Los Angeles: California Association for Bilingual Education.

Cummins, J. (2008). BICS and CALP: Empirical and theoretical status of the distinction. In B. Street \& N. H. Hornberger (Eds.), Encyclopedia of language and education (2nd ed., pp. 71-83). New York, NY: Springer.

Dunn, W. (2011). Working toward social inclusion through concept development in second language teacher education. In K. E. Johnson \& P. R. Golombek (Eds.), Research on second language teacher education: A sociocultural perspective on professional development (pp. 50-64). New York, NY: Routledge.

Grosjean, F. (2008). Studying bilinguals. Oxford, UK: Oxford University Press.

Harris, V., \& Grenfell, M. (2004). Language learning strategies: A case for cross-curricular collaboration. Language Awareness, 13(2), 116-130. doi:10.1080/09658410408667090 
Herdina, P., \& Jessner, U. (2002). A dynamic model of multilingualism: Perspectives of change in psycholinguistics. Clevedon, UK: Multilingual Matters.

Howard, J. (2006). Report for the Canadian Association of Second Language Teachers relating to the survey of core French and French immersion teachers: Data tabulation and analysis of open-ended questions 31 and 38. Ottawa, ON: Canadian Association of Second Language Teachers.

Jessner, U. (2008). A DST model of multilingualism and the role of metalinguistic awareness. Modern Language Journal, 92(2), 270-283. doi:10.1111/j.1540-4781.2008.00718.x

Kemp, C. (2007). Strategic processing in grammar learning: Do multilinguals use more strategies? International Journal of Multilingualism, 4(4), 241-261. doi:10.2167/ijm099.0

Levine, G. S. (2014). Principles for code choice in the foreign language classroom: A focus on grammaring. Language Teaching, 47, 3, 332-348. doi:10.1017/S0261444811000498

Lo, Y. Y. (2015). How much L1 is too much? Teachers' language use in response to student abilities and classroom interaction in Content and Language Integrated Learning. International Journal of Bilingual Education and Bilingualism, 18(3), 270-288. doi:10.1017/S0261444811000498

Macaro, E. (1997). Target language, collaborative learning and autonomy. Clevedon, UK: Multilingual Matters.

Mady, C. (2011). Moving toward inclusive French as a second official language in Canada. International Journal of Inclusive Education, 17(1), 47-59. doi:10.1080/13603116.2011.580463

Mady, C. (2013). Learning French as a second official language in Canada: Comparing monolingual and bilingual students at Grade 6. International Journal of Bilingual Education and Bilingualism, 17(3), 330-344. doi:10.1080/13670050.2013.767778

Mady, C. (2017). The bilingual advantage for immigrant students in FI in Canada: Linking advantages to contextual variables. International Journal of Bilingual Education and Bilingualism, 20(3), 235-251. doi:10.1080/13670050.2015.1041875

Mady, C., \& Arnett, K. (2017). Core or immersion? Canadian French Second Language (FSL) teacher candidates' perceptions and experiences of the best/worst FSL program options for students with learning difficulties and English language learner (ELL) students. Exceptionality Education International, 2(1), 17-37.

Moore, D. (2006). Plurilingualism and strategic competence in context. The International Journal of Multilingualism, 3(2), 125-138. doi:10.1080/14790710608668392

Moore, D. (2010). Multilingual literacies and third script acquisition: Young Chinese children in FI in Vancouver, Canada. International Journal of Multilingualism, 7(4), 322-342. doi:10.1080/14790718.2010.502231

Moore, D., \& Sabatier, C. (2014). Les approches plurielles et les livres plurilingues. De nouvelles ouvertures pour l'entrée dans l'écrit en milieu multilingue et multicultural. [Using multilingual books in schools. Pluralistic approaches for literacy development in multilingual and multicultural contexts]. Nouveaux Cahiers de la Recherche en Éducation, 17(2), 32-65.

Netten, J., \& Germain, C. (2005). Pedagogy and second language learning: Lessons learned from intensive French. Canadian Journal of Applied Linguistics, 8(2), 183-210.

Netten, J., \& Germain, C. (2009). The future of intensive French in Canada. Canadian Modern Language Review, 65(5), 757-786. doi:10.3138/cmlr.65.5.757 
Ontario Ministry of Education. (1998). The Ontario curriculum: French as a second language: Core French grades 4-8. Toronto, ON: Author.

Ontario Ministry of Education. (2013). The Ontario curriculum: French as a second language: Core French grades 4-8, extended French grades 4-8, French immersion grades 1-8. Toronto, ON: Author.

Palmer, D. K. Mateus, S. G. Martínez, R. A., \& Henderson, K. (2014). Reframing the debate on language separation: Toward a vision for translanguaging pedgagogies in the dual language classroom. The Modern Language Journal, 98(3), 757- 772. doi:10.1111/j.15404781.2014.12121.x

Salvatori, M. J. (2007). Learning, discerning and yearning: The development of language proficiency of non-native speaker French as a second language teachers in Ontario (Doctoral dissertation). University of Toronto, ON. Retrieved from https://search.library.utoronto.ca/details?6259994

Turnbull, M. (2001). There is a role for the L1 in second and foreign language teaching, but... . Canadian Modern Language Review, 57(4), 531-540. doi:10.3138/cmlr.57.4.531

Turnbull, M., \& Arnett, K. (2002). Teachers' uses of the target and first languages in the classroom. Annual Review Of Applied Linguistics, 22, 204-218. doi:10.1017/S0267190502000119

${ }^{\mathrm{i}}$ French immersion is a program in which students study subjects in French for at least $50 \%$ of the day; intensive French is a program where students study in French for one term during Grade 5 or 6; in the core French program students study French for approximately one period a day beginning in Grade 4. 